IVA MIKULIĆ, M.Sc. ${ }^{1}$

(Corresponding author)

E-mail: iva.mikulic@cvh.hr

IGOR BOŠKOVIĆ, LL.M. ${ }^{1}$

E-mail: igor.boskovic@cvh.hr

GORAN ZOVAK, Ph.D. ${ }^{1,2}$

E-mail: goran.zovak@cvh.hr

${ }^{1}$ Center for Vehicles of Croatia

Capraška 6, 10000 Zagreb, Croatia

2 University of Zagreb

Faculty of Transport and Traffic Sciences

Vukelićeva 4, 10000 Zagreb, Croatia
Human - Transport Interaction Original Scientific Paper Submitted: 19 Dec. 2019 Accepted: 2 Aug. 2020

\title{
EFFECTS OF DRIVING STYLE AND VEHICLE MAINTENANCE ON VEHICLE ROADWORTHINESS
}

\begin{abstract}
Vehicles that are non-roadworthy pose a hazard for all road users and can be one of the main causes of traffic accidents. Previous studies have analysed the impact of the driving style on environmental sustainability and road safety. Starting from this, there was a need to further investigate the relationship between the driving style and vehicle roadworthiness as well. Vehicles that do not comply with the prescribed requirements should be excluded from traffic at a periodic technical inspection. However, the causes of detected vehicle defects cannot be established at a periodic technical inspection. The paper therefore, examines the factors affecting vehicle roadworthiness. First, the failure rate and mileage of vehicles at periodic technical inspection regarding the type of ownership was examined. In addition, a questionnaire was conducted to collect data about the driving style and maintenance habits of different types of car owners. The paper argues that vehicles owned by legal entities were generally in a worse condition than the vehicles owned by natural persons, due to the increased vehicle exploitation, but also due to a more aggressive driving style. Finally, it was found that by modifying their driving style, the drivers can affect the condition of their vehicles, considering the same mileage and maintenance habits.
\end{abstract}

\section{KEY WORDS}

periodic technical inspection; vehicle roadworthiness; driving style; vehicle maintenance; driving behaviour;

\section{INTRODUCTION}

Based on the Spanish case and data collected from different sources (the Ministry of Industry, the General Directorate for Traffic, vehicle manufacturers, etc.), the analysis of Periodic Technical Inspections (PTI) of vehicles shows that around
$15 \%$ of traffic accidents were directly related to vehicle defects [1]. By investigating the correlation between vehicle age and traffic accident rate, the author in [2] provides evidence that the accident rate decreased as the result of the Japanese PTI system, especially in the inspection years. Although the accidents were in some cases caused by other factors, and not by the existing vehicle defects, their presence can significantly worsen the situation and make the accidents much more serious. It is therefore in public interest to ensure that only technically reliable vehicles participate in traffic.

Since the maintenance of vehicles is of the highest importance for road safety, the government in the Republic of Croatia legally obligated the PTI system [3]. PTI of vehicles is carried out for the benefit of the public in order to prevent vehicles that do not comply with the prescribed requirements to participate in traffic. The authors in [3] emphasize the direct effect that the exclusion of defective vehicles from road traffic has on the raising of the road traffic safety level. PTI in the Republic of Croatia is carried out by authorised legal entities at PTI stations. The Center of Vehicles of Croatia $(\mathrm{CVH})$, an authorised public legal entity that organizes and coordinates work of PTI stations in Croatia, provided data that were collected in the vehicle database, and were therefore analysed in this paper.

One of the factors that affect road safety is vehicle roadworthiness. Vehicle maintenance includes a number of measures and procedures that are regularly carried out in order to check and ensure vehicle roadworthiness. Repairing the detected defects and replacing the worn-out parts keeps the vehicle in proper technical condition. According to [4], the 
intensity of maintenance of a vehicle is determined by the number of kilometres travelled by the vehicle in an observed period of time. There is a significant influence of mileage on vehicle condition, which is frequently analysed in literature. Accordingly, the authors in [5] examine the impact of vehicle maintenance and PTI on the vehicle roadworthiness and establish that vehicles with a greater mileage have more often been declared technically defective. However, there are also many factors that can influence the vehicle roadworthiness as well. In most cases, vehicle age significantly affects vehicle roadworthiness and, consequently, the result of the PTI. With aging, individual vehicle parts are more prone to breakdowns and material fatigue, such as rubber elements. However, the impact of age and greater mileage on the overall condition of the vehicle can be negligible if it is maintained regularly and driven responsibly.

The authors of [6] state that vehicle defects contribute to traffic accidents to a much greater extent than suggested by the police statistics, in order to divert the attention to the driving style and behaviour of the driver as a road user. Essentially, the driving style is the way a driver accelerates, drives, and brakes. The authors in [7] define the driving style as a driving habit that is formed over a period of time, most often over several years. Objectively speaking, there are numerous elements in a person's driving behaviour that are used to determine their driving style. The authors in [8] differentiate between the terms driving style and driving behaviour. Driving style is influenced by the person's personality, as well as their physical and mental condition, and is manifested in the driving behaviour. They also establish three types of driving style - aggressive, moderate, and conservative. Furthermore, according to [9], the driving style can be classified into three categories as well - calm, normal, and aggressive. The aggressive driving style generally implies driving at higher speeds, frequent overtaking, driving at higher Revolutions per Minute (RPMs), open windows, and hard acceleration and braking [10]. In contrast, careful driving style means driving at lower speeds, avoiding unnecessary overtaking, driving at lower RPMs, and gentle acceleration and braking. A combination of these two driving styles, where neither predominates, results in the driving behaviour that can be adjusted to the conditions on the road. In addition, the more extensive literature focused on the driving style and its influence is reviewed.
The next section provides a literature review regarding the driving style effect on road safety and fuel consumption. The third section describes the method used for analyzing the factors influencing vehicle condition, i.e. vehicle roadworthiness. In the fourth section the results are reported and discussed, and in the final section some conclusions are provided.

\section{LITERATURE REVIEW}

Some literature studies $[10,11]$ investigate the impact of the driving style on the reduction of gas emissions by analysing the concept of eco-driving, considering its benefits and limitations. According to [11], eco-driving can be defined as a decision-making process - strategic (vehicle maintenance), tactical (trip planning), and operational (driving) decisions that contribute to reductions in fuel consumption and gas emissions. Other authors were inspired by defining the driving factors that affect fuel consumption. According to $[12,13]$, by altering the driver's driving style, it is possible to improve fuel consumption and emission by $40 \%$. The research presented in [7] establishes the importance of the driving factors and their impact on fuel consumption by using the Analytical Hierarchy Process (AHP) method. It was found that factors 'driver awareness' and 'vehicle control' were the two most influential categories regarding fuel consumption. In their study [14], the driving style factors were analysed to find the impact on fuel economy. The authors used a set of polynomial metamodels and found that by optimization of factor coefficient of power demand it is possible to affect fuel consumption. By improving their driving style and driving behaviour, the drivers make better choices, which results in decreased fuel consumption and vehicle maintenance costs as well [15].

A significant research effort has been focusing on investigating the impact of the driving style on the environmental sustainability. The aim is to increase awareness of the vehicle use. Accordingly, the fact is that the driving style significantly contributes to the way the vehicle is used. It ultimately affects both the reduction of gas emissions and the fuel consumption, two topics frequently addressed in the scientific research. Furthermore, it also contributes to the overall road safety.

The authors in [16] establish that excess speed is one of the most significant causes of traffic accidents. Accordingly, the authors in [10] quote that aggressive driving style can be used as a "catch-all" for all 
vehicle operations that are not eco-driving, which include excessive speed as well. The authors in [17] identify links between the driving style and road safety. Furthermore, they reviewed individual and socio-cultural factors influencing the driving style. The authors in [18], by conducting surveys to collect experimental speed values and by using smart-phoneequipped vehicles to record continuous speed data, found that only four drivers drove in a safe manner.

The definition of the driving style is a subject of many recent studies. A significant research effort has been focusing on investigating the most appropriate method for collecting data on the driving style. Many studies have focused on using questionnaires to collect data on the driving behaviour and driving style, which yielded promising results. However, this kind of studies is based only on the drivers' self assessment. The results shown in [19] concluded that the behavioural-emotional latent construct weighs on average $30 \%$ more than the somatic-emotional latent construct, with a positive effect on the driving style. The authors based their research on the combination of the drivers' self-evaluation data and vehicle real test data. Accordingly, they highlighted that the weight of subjective driving style evaluation is equal to twice the objective evaluation. The authors of [8], however, used an Electroencephalography (EEG) device to collect data for their driving style recognition model. Collecting data through a questionnaire may be a somewhat subjective and indirect method for evaluating the driving style. However, a driver wearing an EEG cap would be aware of it and in certain situations would likely act differently than usual. Research presented in [20] shows that inertial sensors used to determine the driving style can easily distinguish between the driving styles of different drivers that have used the vehicle. By comparing the driving style data collected through the Multidimensional Driving Style Inventory (MDSI) questionnaire with the data collected using a driving simulator, the authors of [21] find significant correlation between the obtained results and conclude that the results obtained using a questionnaire represent a sufficient indicator for determining the driving style, regardless of the high level of subjectivity.

Given that only a small number of papers examine the impact of the driving style on vehicle roadworthiness, as well as the causes of individual technical defects identified during PTI, the literature review indicated the need for such a research. As mentioned in [22], the causal relation between vehicle age and the result of PTI is intuitively assumed. However, an assumption can be proved by conducting analysis of data collected in PTI stations. This kind of analysis is periodically conducted within $\mathrm{CVH}$ and will not be shown as part of this paper. Furthermore, the author concluded that the quality of maintenance correlates with the vehicle age. It also follows that the more vehicle is used, the more likely it is to be defective. Moreover, the owners who are less concerned with safety tend to equally neglect the technical condition of their vehicles, with the causal link between vehicle roadworthiness and its use and, as a result, their impact on the overall road safety [23]. Therefore, the research hypothesis proposes that the driving style affects the vehicle condition, regardless of the frequency of vehicle maintenance and vehicle age.

\section{METHODOLOGY}

In order to determine the differences in the driving style, we started with the assumptions based on experience. The assumption concerned differences in the condition of the vehicles that underwent PTI with respect to the vehicle ownership. Starting from this consideration, in this paper, we argued that vehicles owned by natural persons are used more carefully in the context of the driving style and are in a better technical condition than the vehicles owned by legal entities, regardless of the fact that legal entities and leasing companies maintain their vehicles more frequently. Considering this, we proposed a methodology of conducting analysis of data regarding vehicle ownership collected at PTI stations during PTI and comparing these with the results obtained using a questionnaire as an indicator for determining the driving style and vehicle maintenance routine.

\subsection{PTI data analysis}

The paper first analysed data on vehicle failure rates with respect to the type of vehicle ownership. It included data recorded during PTIs carried out in the period from 2013 to 2017. During that period, applicable regulations mandated that new vehicles undergo PTI in the last month in which the 24-month period from the first technical inspection and registration expired. Vehicles that were two or more years old had to undergo PTI every 12th month since the last PTI. During PTI, the data on the vehicle are recorded, logged in the databases, 
and printed on vehicle registration documents, and as such are considered the essential part of the technical inspection process [22]. Data analysed in this research include the M1 category vehicles. M1 category of vehicles refers to vehicles that are designed and constructed for the carriage of passengers and comprising no more than eight seats in addition to the driver's seat. Since M1 category vehicles, or in other words, passenger cars, comprised around $76 \%$ of total registered vehicles in the Republic of Croatia in the period $2008-2017$, the research was limited to them [24]. The previously mentioned makes them the most widely represented category of vehicles, and a category that is most often involved in traffic accidents. In 2017, there were 30,292 passenger cars involved in traffic accidents, which compared to other vehicle categories represents a high $69.56 \%$ [25].

The data on vehicles up to 10 years of age were collected, with the vehicles divided into four age intervals: 1-3, 4-5, 6-7 and 8-10 years of age. By analysing the data on annual mileage of M1 vehicles, as shown in [26], it was evident that after 10 years the sample of such vehicles is on average twice as high. However, we have analysed vehicles up to 10 years of age in order for the analysis according to the type of ownership to be as relevant as possible, since leased vehicles are the subject of contract during a significantly shorter period. In order to obtain accurate results, the analysis included only the vehicles that have not changed the ownership, i.e. vehicles that were owned by a natural person or a legal entity, i.e. leased continuously. Vehicles with less than 2,000 $\mathrm{km}$ on the odometer were not included in the analysis of vehicle odometer readings.

As the vehicle manufacture year and odometer reading are also logged at the PTI, these data were as well included in the analyses. Therefore, the paper in addition analyses data on vehicle failure rates in relation to mileage, regarding vehicle ownership. For the purpose of the analysis, odometer readings of the vehicles within the observed sample were shown as average annual mileage of an individual vehicle, and were taken as the most direct indicator for measuring vehicle use available [22]. Thus, if a vehicle travels many kilometres during a relatively short time, its parts and assemblies are exposed to heavier loading, increased wear, and therefore are more likely to develop corrosion and material fatigue faster. Obviously, the average annual mileage as a factor, greatly affects the vehicle condition, i.e. vehicle roadworthiness. However, the question arose whether the driving style also affects vehicle roadworthiness. To answer this question, data on the roadworthiness of vehicles within each age interval and with approximately the same mileage needed to be analysed. Accordingly, the analyzed data were divided into 13 mileage intervals regarding vehicle ownership and four previously defined age intervals.

\subsection{Questionnaire structure}

Data on the driving style and vehicle maintenance habits were collected using questionnaires that were completed by individuals whose vehicles underwent PTI during the observed period. In accordance with the previous section, the restriction applied to M1 vehicles up to ten years old. Data collection by using questionnaires was conducted in ten PTI stations in Croatia. All of ten PTI stations were located in Zagreb and there were no significant differences between them, except regarding their size, number of employees, and the part of the city where they were located. As Zagreb is the largest city in Croatia, there was a greater fluctuation of people, greater heterogeneity of ownerships, as well as greater possibility of data collection in the desired period of time.

The questionnaire consisted of 14 questions and was divided into three sections: basic information regarding vehicle ownership, driving style, and vehicle maintenance. Among other, the respondents used the questionnaire to self-assess their driving style by selecting one of the following options: careful, adjustable to road conditions, or aggressive. In order to provide better understanding of the proposed options to the respondents, three driving style categories that were described in the introduction, were linguistically transformed. However, the definitions still remained unchanged. In addition, the respondents self-assessed their driving speed by selecting slow, moderate, or fast. Since several different individuals may use one vehicle, which is most often the case with vehicles owned by legal entities and leased vehicles, there is a chance of misinterpretation of data. In order to eliminate such cases from the sample, the questionnaire in its first section (basic information regarding vehicle ownership) included the question on the number of drivers that normally use the same vehicle.

In order to assess the impact of vehicle maintenance on roadworthiness, it was essential to determine the driver's habits with regard to vehicle 
maintenance. These data were also collected from the respondents' replies to the question of the frequency of servicing of their vehicles. The respondents could select one of the following answers: more than once a year, once a year, or as needed. Moreover, the question regarding the maintenance method was raised. The possible answers included: authorized service center, car mechanic shop, independently, or other.

The comparison of the data on the failure rate of vehicles with the driving style and vehicle maintenance data helped to establish their interrelation.

\section{RESULTS}

The section below presents the results and their interpretation in the order in which the research was conducted. Data on PTI performed from 2013 to 2017 were obtained from the $\mathrm{CVH}$ database and were further analysed. The questionnaire data regarding the driving style and vehicle maintenance were gathered in PTI stations and were therefore statistically analysed.

\subsection{Roadworthiness in relation to the type of vehicle ownership}

The first part of the analysis included an analysis of vehicle failure rate regarding vehicle ownership. By analysing data on vehicle roadworthiness in the observed period of 2013-2017, it was found that the vehicles owned by natural persons generally had a higher rate of roadworthiness, i.e. lower failure rate than vehicles owned by legal entities within the same age interval. Increasing the age interval usually results with a greater difference in the failure rate. Specifically, the average difference in the failure rate between vehicles owned by natural persons and vehicles owned by a legal entity is 0.88 in the interval of 1-3 years, in the interval of 4-5 years $1.65,2.24$ in the interval of 6-7 years, and 2 in the 8-10 years interval. The deviation was observed in the age interval of 8-10 years, where the vehicles owned by legal entities-leasing have a lower failure rate in some years compared to vehicles owned by natural persons. This is due to a very small sample of such vehicles, as vehicle leases are in most cases concluded for a shorter time period, which makes the data incomparable. Thus, data in $8-10$ years interval may be negligible. The previously described results are shown in Figure 1, while the failure rate according to the ownership and in relation to age intervals are shown in the corresponding table.

\subsection{Roadworthiness in relation to mileage}

After obtaining the initial results which corroborate the premise that the vehicles owned by natural persons generally have a higher rate of

$$
{ }^{[\%]} 25
$$

20

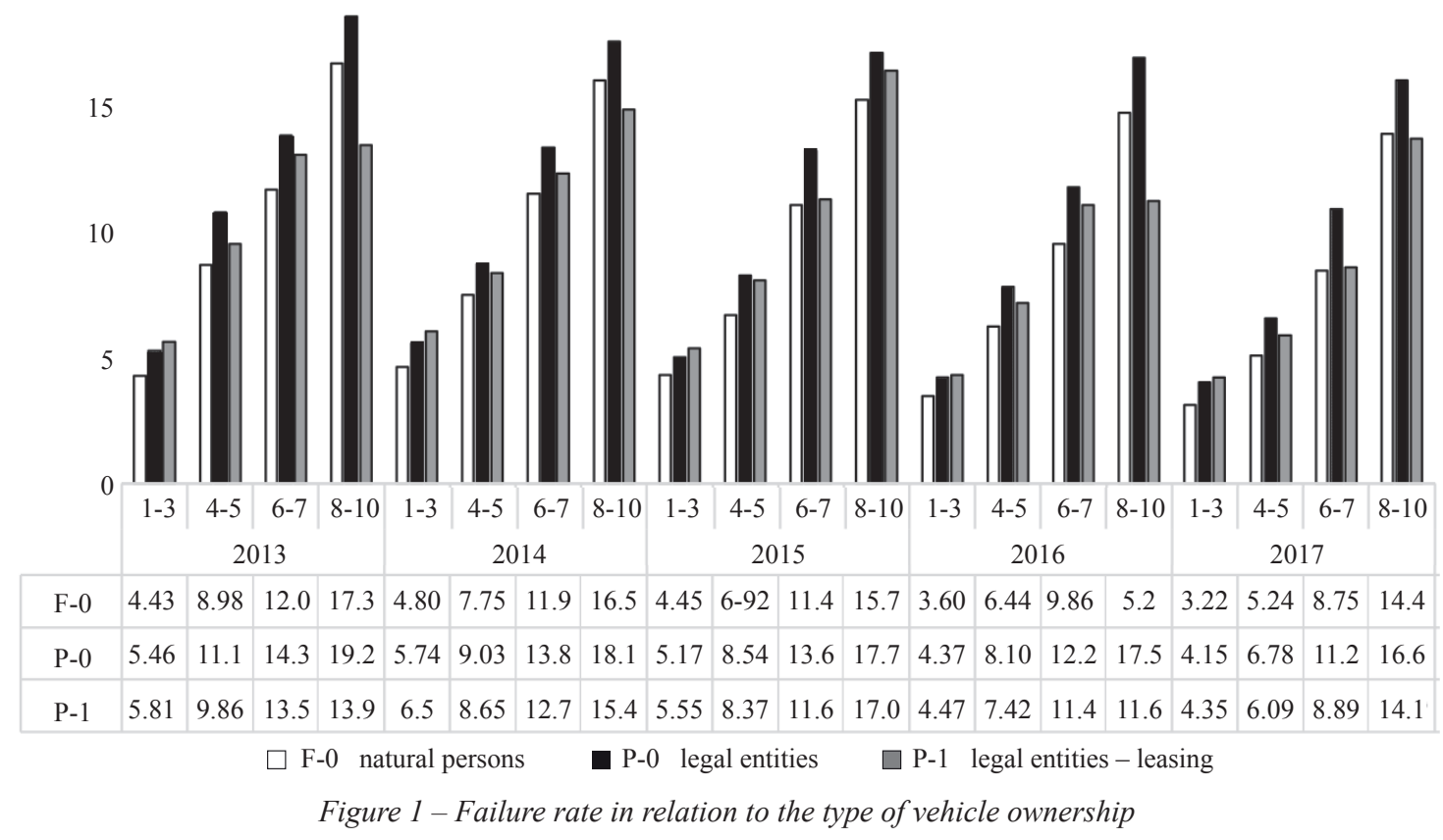


roadworthiness than vehicles owned by legal entities, it was necessary to establish the reasons behind such tendencies. The data on mileage for individual types of vehicle ownership were used as the baseline. The data are shown in Figure 2.

By analysing the data on mileage, it can be concluded that vehicles owned by natural persons in all age intervals have significantly lower mileage than vehicles owned by legal entities and legal entities-leasing. It can therefore be concluded that heavily used vehicles, as can be expected, have more failures. The vehicle, just as any other machine, is subjected to increased wear and tear brought on by heavy use.
However, the question arose whether the driving style also affected vehicle roadworthiness. To answer this question, the data on the roadworthiness of vehicles within each age interval and with approximately the same mileage needed to be analysed. The results are shown graphically in Figures 3-6.

It is evident from the shown data that vehicles within the same age interval and with approximately equal mileage, owned by natural persons, have in most cases higher rate of roadworthiness than vehicles owned by legal entities and vehicles owned by legal entities-leasing. The fact that the sample of the leased vehicles older than 5 years is small must also be taken into account. Considering this evidence,

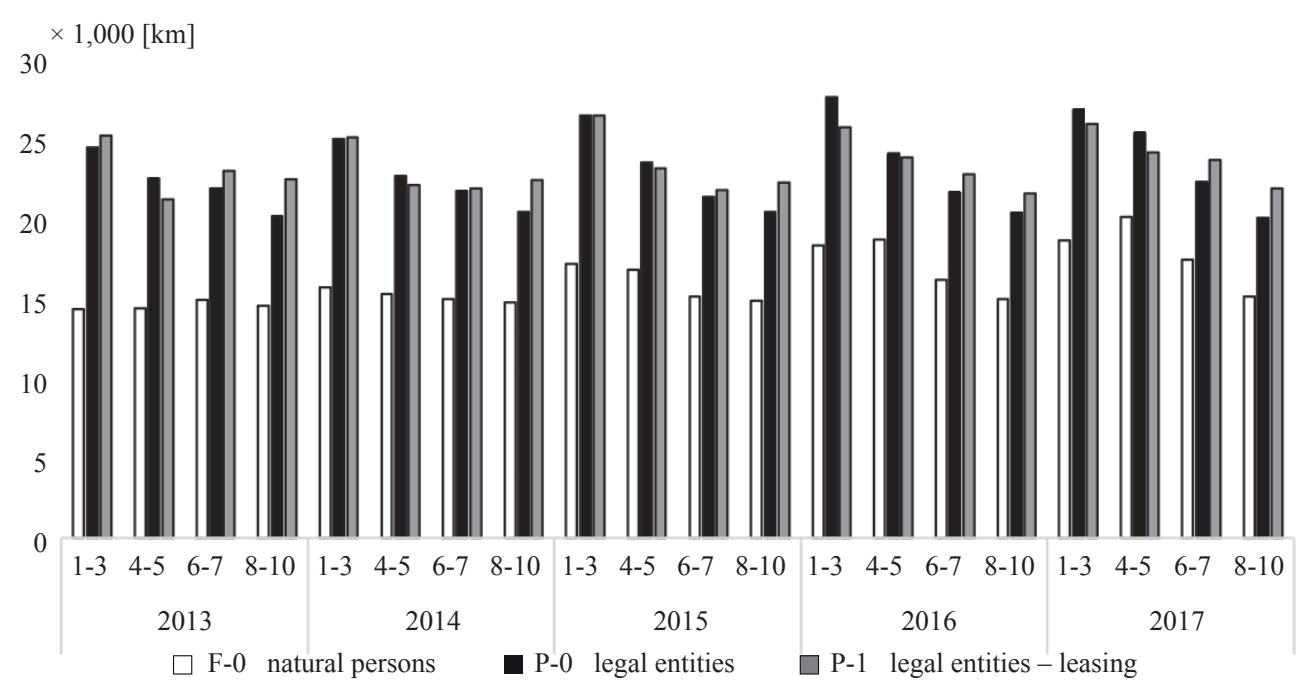

Figure 2 - Average annual mileage in relation to vehicle ownership within observed intervals

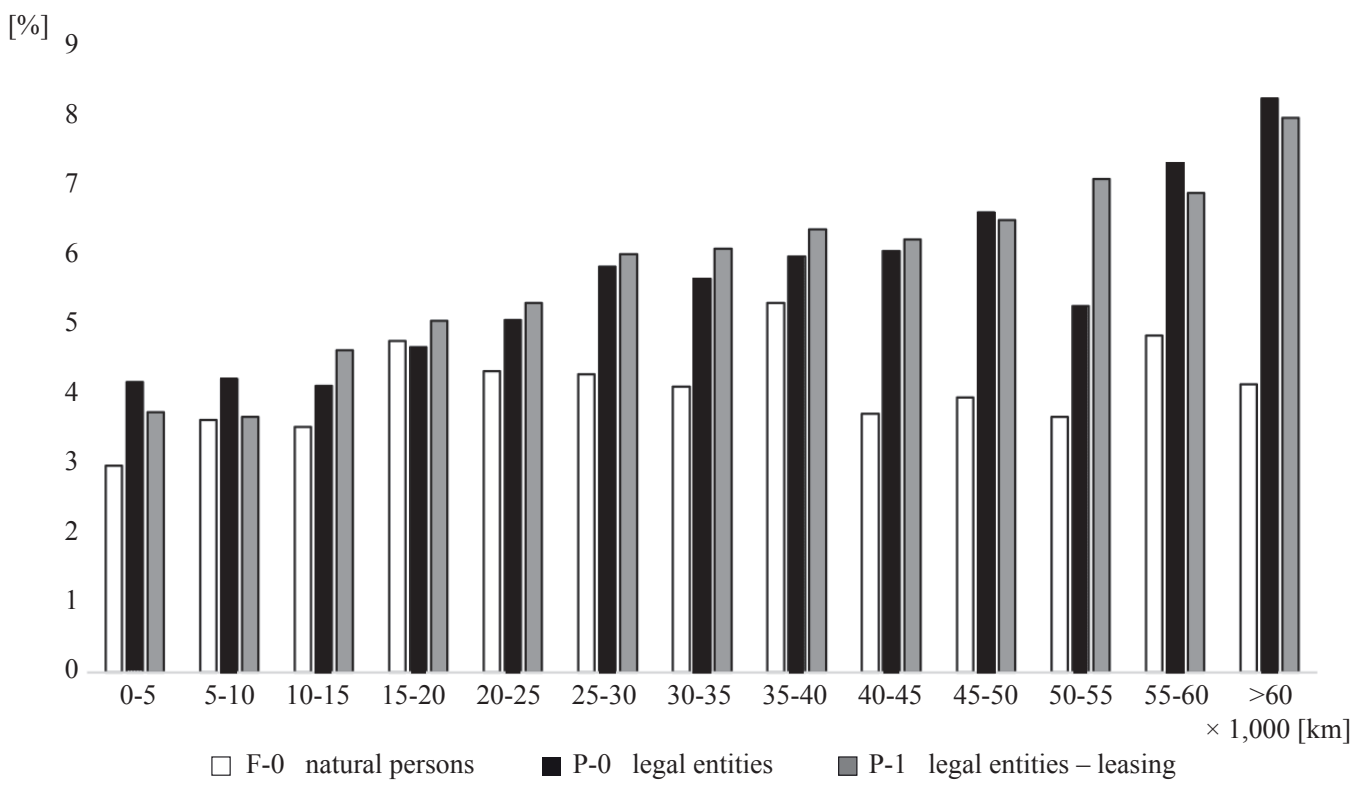

Figure 3 - Failure rate for vehicles 1-3 years old, with approximately equal mileage 
$[\%]$

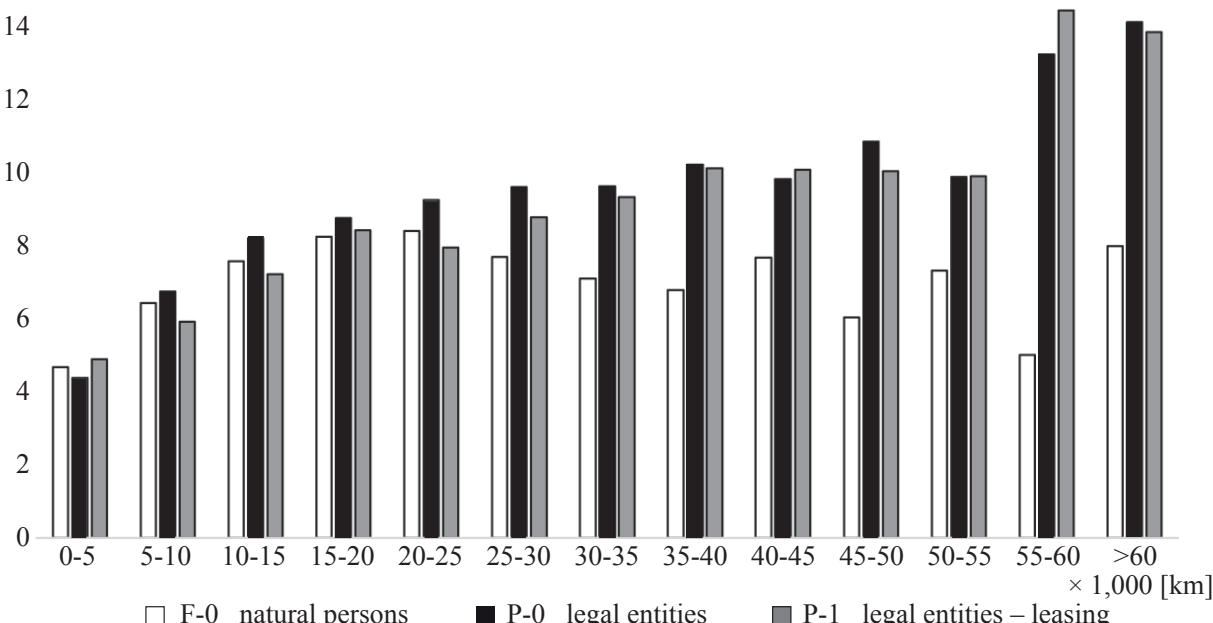

$\square$ F-0 natural persons

P-0 legal entities

$\square$ P-1 legal entities - leasing

Figure 4 - Failure rate for vehicles 4-5 years old, with approximately equal mileage

$[\%] 25$

20

5

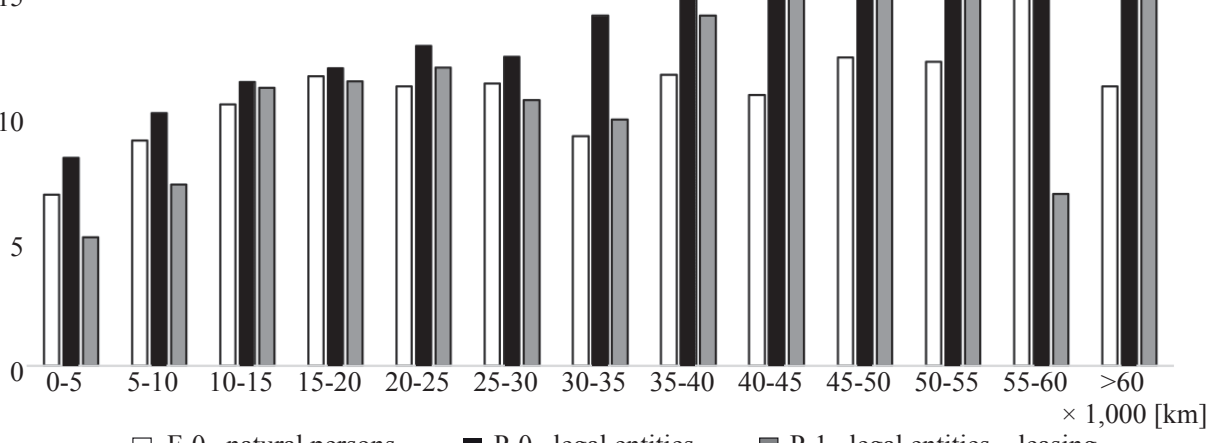

$\square$ F-0 natural persons

- P-0 legal entities

$\square$ P-1 legal entities - leasing

Figure 5-Failure rate for vehicles 6-7 years old, with approximately equal mileagea ${ }^{[\%]} 60$

50

40

30

20

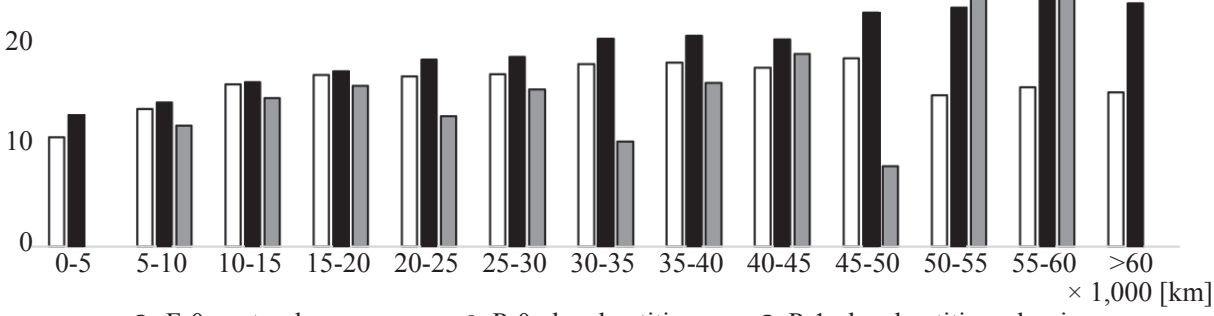

$\bigcirc \mathrm{F}-0$ natural persons

- P-0 legal entities

O P-1 legal entities - leasing

Figure 6-Failure rate for vehicles 8-10 years old, with approximately equal mileage 
roadworthiness is not causally related to just mileage; the way the vehicle is used in traffic and regular maintenance play an important role as well.

\section{DISCUSSION}

The questionnaire data collection was conducted at ten PTI stations in Croatia in the capital city of Zagreb. In each of the ten PTI stations 100 blank questionnaires were distributed. Of the planned 1,000 , there were 732 respondents who accessed the questionnaire. Thus, the response rate was $73.2 \%$, which represented a suitable sample. From the total number of 732 respondents there were $71.45 \%$ natural persons, $18.03 \%$ legal entities and $10.52 \%$ legal entities-leasing. The respondents were familiar with anonymity when conducting the research to make the data more relevant.
Regarding vehicle maintenance, the research is shown in Figure 7. We can thus conclude that both natural persons and legal entities equally maintain their vehicles. Furthermore, maintenance habits go in favour of legal entities, with a high percentage of them servicing their vehicles more than once a year. Nevertheless, they still have a higher failure rate at the periodic technical inspection. It is common knowledge that regular and proper maintenance has a positive effect on vehicle roadworthiness. However, vehicle owners tend to neglect this aspect of vehicle use, either due to negligence or due to related financial costs. Naturally, vehicles that are not regularly maintained are more liable to defects.

However, when it comes to the driving style, the results shown in Figure 8 differ significantly. Research shows that $3.06 \%$ of natural persons, $8 \%$ of legal entities and $6.5 \%$ of legal entities-leasing

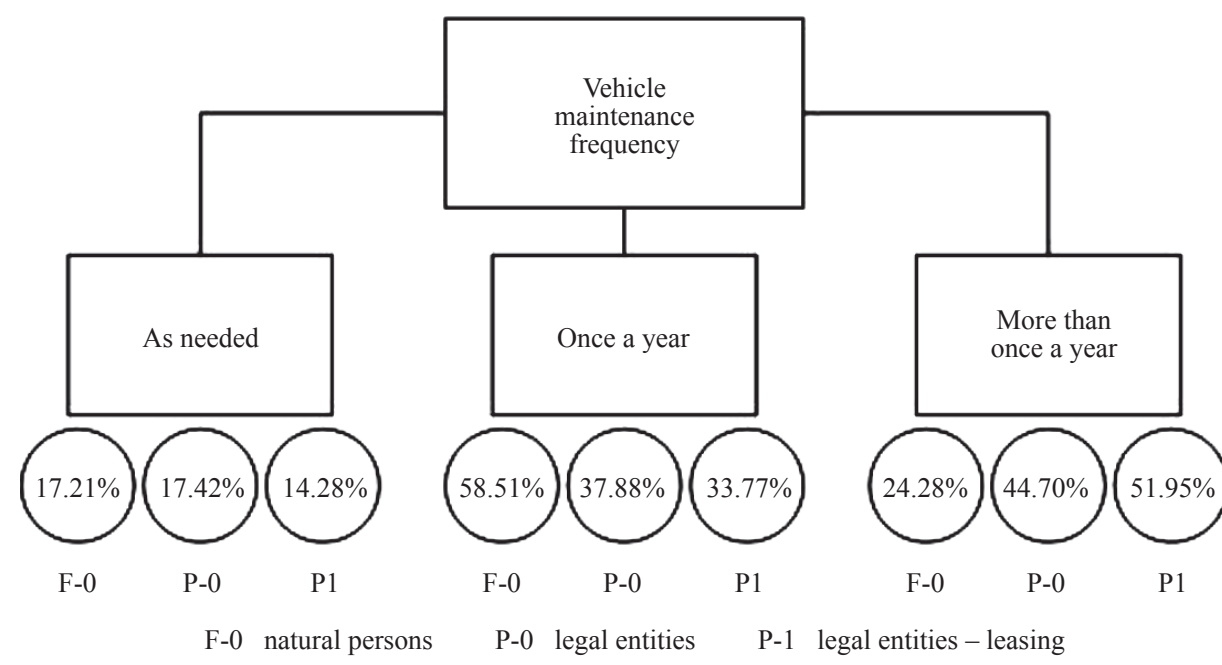

Figure 7 -Vehicle maintenance frequency - questionnaire results

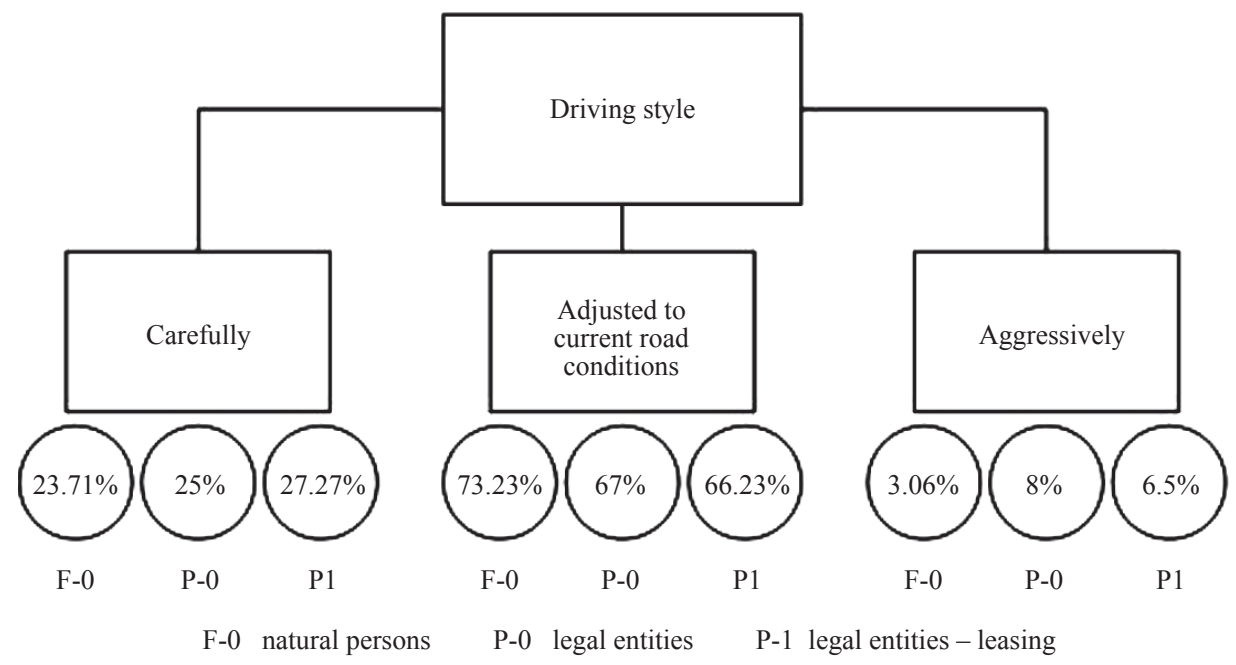

Figure 8-Driving style - questionnaire results 


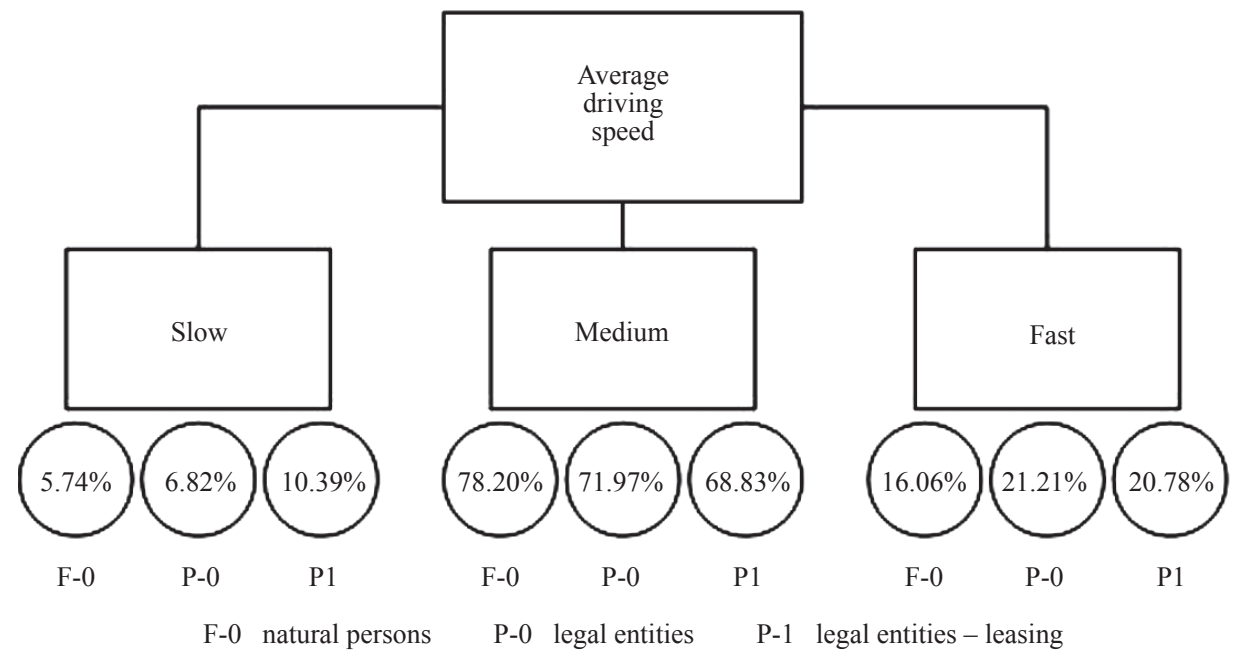

Figure 9 - Average driving speed - questionnaire results

drive aggressively, which shows that vehicles owned by legal entities and legal entities-leasing are subjected to aggressive driving much more than vehicles owned by natural persons.

If we only look at the driving speed parameter as presented in Figure 9, we can also conclude that natural persons drive their cars more carefully in comparison to vehicles owned by legal entities.

Comparing the results of vehicle roadworthiness with the results obtained from conducting questionnaires, it was found that worse technical condition of vehicles owned by legal entity and legal entity-leasing is one of the consequences of a worse driving style.

\section{CONCLUSION}

By analysing the previously described results, it can be concluded that the driving style is one of the key factors affecting vehicle roadworthiness, implying frequent vehicle maintenance as a prerequisite for vehicle participation in road traffic. Aggressive and fast driving subjects the mechanical assemblies of the vehicle to increased load, which in turn results in higher failure rate of vehicles used in such a manner. This negative impact of aggressive driving on vehicle roadworthiness cannot be mitigated even by regular vehicle maintenance, which the majority of owners carry out once to twice a year. Therefore, considering the results of the research, by modifying their driving style, and with the same mileage and same maintenance habits, there is a possibility that the drivers could increase the roadworthiness condition of their vehicles, and thus reduce the risk of a mechanical defect causing a traffic accident.
The enforcement of police traffic control measures can partially impact the driving style. However, greater emphasis should be put on the prevention, as aggressive driving does not necessarily imply the violation of traffic rules. For instance, hard acceleration with high RPMs does not constitute a traffic offence, but the vehicle is thereby unnecessarily subjected to excessive load. Therefore, the key measures that would contribute to the modification of the driving style should be educational, and lead to the adoption of patterns of traffic behaviour that do not include aggressive driving. Consequently, this would help to increase vehicle roadworthiness and reduce the number of traffic accidents.

The limitations of the conducted research refer to the collection of data on the driving style and vehicle maintenance, which were collected using a questionnaire completed by respondents whose vehicles underwent PTI at a PTI station. Although such data were considered sufficiently relevant to support the hypotheses proposed in research papers [21, 27], the authors in paper [8] warn of their subjective and indirect nature. Therefore, future research should be focused on providing a more relevant method for collecting data regarding the driving style recognition. Furthermore, by limiting research to Zagreb, that is, the capital city of Croatia, there was a possibility that greater differences regarding purchasing power of people were excluded, which could have been significant in the context of vehicle maintenance.

IVA MIKULIĆ, mag. ing. mech. ${ }^{1}$

E-mail: iva.mikulic@cvh.hr

IGOR BOŠKOVIĆ, mag. iur. ${ }^{1}$

E-mail: igor.boskovic@cvh.hr 
Prof. dr. sc. GORAN ZOVAK, dipl. ing. stroj. ${ }^{1,2}$

E-mail: goran.zovak@cvh.hr

${ }^{1}$ Centar za vozila Hrvatske d.d.

Capraška 6, 10000 Zagreb, Hrvatska

${ }^{2}$ Sveučilište u Zagrebu, Fakultet prometnih znanosti

Vukelićeva 4, 10000 Zagreb, Hrvatska

\section{UTJECAJ NAČINA VOŽNJE I ODRŽAVANJA VOZILA NA TEHNIČKU ISPRAVNOST VOZILA}

\section{SAŽETAK}

Neispravna vozila predstavljaju opasnost za sve sudionike u prometu te su potencijalni uzročnici prometnih nesreća. Prethodno provedena istraživanja analizirala su utjecaj načina vožnje na okolišnu održivost i na sigurnost prometa na cestama. Međutim, jednako tako je potrebno istražiti odnos između načina vožnje i tehničke ispravnosti vozila. Vozila koja ne udovoljavaju propisanim uvjetima eliminiraju se iz prometa na tehničkom pregledu vozila. Međutim, na tehničkom pregledu se utvrđuje je li vozilo ispravno, a ne utvrđuju se uzroci utvrđenih neispravnosti. U ovome radu analizirani su upravo čimbenici koji utječu na tehničku ispravnost vozila. Prvo je istražen udio neispravnih vozila na tehničkom pregledu te broj prijeđenih kilometara ovisno o vrsti vlasnika vozila. Zatim su pomoću upitnika prikupljeni podaci o načinu vožnje i navikama održavanja vozila različitih vrsta vlasnika. Iznijeta je teza da su vozila u vlasništvu pravnih osoba u pravilu u lošijem tehničkom stanju od onih $u$ vlasništvu fizičkih osoba, zbog veće eksploatacije vozila, ali i zbog veće sklonosti agresivnoj vožnji vozača takvih vozila. Konačno, utvrđeno je da promjenom načina vožnje vozači mogu, uz jednaki broj prijeđenih kilometara $i$ jednake navike održavanja vozila, utjecati na tehničko stanje svojih vozila.

\section{KLJUČNE RIJEČI}

redovni tehnički pregled vozila; tehnička ispravnost vozila; način vožnje; održavanje vozila;

ponašanje vozača;

\section{REFERENCES}

[1] Boada BL, Boada MJL, Ramirez M, Diaz V. Study of van roadworthiness considering their maintenance and periodic inspection. The Spanish case. Transportation Letters - The International Journal of Transportation Research. 2014;6(4): 173-184. Available from: doi:10.1 179/1942787514Y.0000000023

[2] Saito K. Evaluating Automobile Inspection Policy Using Auto Insurance Data. Contemporary Economic Policy. 2009;27(2): 200-215. Available from: doi:0.1111/j.14657287.2008.00108.x

[3] Zovak G, Čala I, Šiško I. Application of standards in auditing of stations for technical inspection of vehicles. Promet - Traffic\&Transportation. 2009;21(3): 191-198.
Available from: doi:10.7307/ptt.v21i3.225

[4] Caban J, Drozdziel P, Krzywonos L, Rybicka I, Šarkan B, Vrabel J. Statistical Analyses of Selected Maintenance Parameters of Vehicles of Road Transport Companies. Advances in Science and Technology Research Journal. 2019;13(1): 1-13. Available from: doi:10.12913/22998624/92106

[5] Škreblin T. Elements of Calculation of Average Annual Mileage for Motor Vehicles. $3^{\text {rd }}$ International scientific conference Lean Spring Summit; 2018. p. 59-71.

[6] Paine M. Vehicle roadworthiness and accidents. Vehicle Design and Research. Victorian Parliament Road Safety Committee; 2000.

[7] Akena R, Schmid F, Burrow M. Driving style for better fuel economy. Proceedings of the Institution of Civil Engineers - Transport. 2017;170(3): 131-139. Available from: doi:0.1680/jtran.15.00116

[8] Yan F, Liu M, Ding C, Wang Y, Yan L. Driving Style Recognition Based on Electroencephalography Data from a Simulated Driving Experiment. Frontiers in Psychology. 2019;10: 1254. Available from: doi:10.3389/ fpsyg.2019.01254

[9] Bao Y, Chen W. A Personalized Route Search Method Based on Joint Driving and Vehicular Behviour Recognition. 2016 IEEE MTT-S International Wireless Symposium (IWS), 14-16 March 2016, Shanghai, China; 2016. Available from: doi:10.1109/IEEE-IWS.2016.7585488

[10] Sanguinetti A, Kurani K, Davies J. The many reasons your mileage may vary: Toward a unifying typology of eco-driving behaviors. Transportation Research Part D. 2017;52: 73-84. Available from: doi:10.1016/ j.trd.2017.02.005

[11] Alam Md.S, McNabola A. A critical review and assessment of Eco-Driving policy \& technology: Benefits \& limitations. Transport Policy. 2014;35: 42-49. Available from: doi:10.1016/j.tranpol.2014.05.016

[12] Manzoni V, Corti A, De Luca P, Savaresi SM. Driving style estimation via inertial measurements. $13^{\text {th }}$ International IEEE Conference on Intelligent Transportation Systems; 2010. p. 777-782.

[13] Van Mierlo J, Maggetto G, Van De Burgwal E, Gense R. Driving style and traffic measures-influence on vehicle emissions and fuel consumption. Proceedings of the Institution of Mechanical Engineers, Part D: Journal of Automobile Engineering. 2004;218(1): 43-50.

[14] Malikopoulos AA, Aguilar JP. Optimization of Driving Styles for Fuel Economy Improvement. Proceedings of the $15^{\text {th }}$ IEEE Conference on Intelligent Transportation Systems (ITSC 2012). 16-19 Dec. 2012, Anchorage, Alaska, USA; 2012. Available from: doi:10.1109/ ITSC.2012.6338607

[15] DriveTech. The impact of driver behaviour on vehicle running costs; 2017. Available from: https://www.drivetech.co.uk/news-and-resources/the-impact-of-driver-behaviour-on-vehicle-running

[16] Zovak G, Kos G, Huzjan B. The Driver Behaviour and Impact of Speed on Road Safety on The Motorways in Croatia. Promet - Traffic\&Transportation. 2017;29(2): 155-164. Available from: doi:10.7307/ptt.v29i2.2071

[17] Sagberg F, Selpi S, Bianchi Piccinini G, Engström J. A Review of Research on Driving Styles and Road 
Safety. Human Factors. 2015;57(7). Available from: doi:10.1177/0018720815591313.

[18] Eboli L, Guido G, Mazzulla G, Pungillo G, Pungillo R. Investigating car users' driving behaviour through speed analysis. Promet - Traffic\&Transportation. 2017;29(2): 193-202. Available from: doi:10.7307/ptt.v29i2.2117

[19] Eboli L, Mazzulla G, Pungillo G. How drivers' characteristics can affect driving style. Transportation Research Procedia. 2017;27: 945-952. Available from: doi:10.1016/j.trpro.2017.12.024

[20] Ly MV, Martin S, Triverdi MM. Driver Classification and Driving Style Recognition using Inertial Sensors. 2013 IEEE Intelligent Vehicles Symposium (IV), 23-26 June 2013, Gold Coast, QLD, Australia; 2013. p. 1040-1045. Available from: doi:10.1109/IVS.2013.6629603

[21] Van Huysduynen HH, Terken J, Eggen B. The relation between self-reported driving style and driving behaviour. A simulator study. Transportation Research Part F. 2018;56: 245-255. Available from: doi:10.1016/ j.trf.2018.04.017

[22] Škreblin T. Model of PTI Stations Work Quality Assessment. Ph.D. thesis. University of Zagreb, Faculty of Mechanical Engineering and Naval Architecture; 2017. Available from: http://repozitorij.fsb. hr/8896/1/\%C5\%A0kreblin_phd_2018.pdf
[23] Christensen P, Elvik R. Effects on accidents of periodic motor vehicle inspection in Norway. Accident Analysis and Prevention. 2007;39: 47-52. Available from: doi:10.1016/j.aap.2006.06.003

[24] Ministarstvo unutarnjih poslova. Bilten o sigurnosti cestovnog prometa u 2017; 2018. p. 65. Available from: https://mup.gov.hr/pristup-informacijama-16/statistika-228/statistika-mup-a-i-bilteni-o-sigurnosti-cestovnog-prometa/283233

[25] Centar za vozila Hrvatske d.d.. Provjera tehničke ispravnosti vozila koja sudjeluju u prometnim nesrećama sa smrtno stradalim osobama. Izvješće o provedenim aktivnostima. Zagreb, Croatia: Centar za vozila Hrvatske d.d.; 2016.

[26] Pejić G, Bijelić F, Zovak G, Lulić Z. Model for Calculating Average Vehicle Mileage for Different Vehicle Classes Based on Real Data: A Case Study of Croatia. Promet - Traffic\&Transportation. 2019;31(2): 213-222. Available from: doi:10.7307/ptt.v31i2.3043

[27] Martinussen LM, Moller M, Prato CG. Assessing the relationship between the Driver Behavior Questionnaire and the Driver Skill Inventory: Revealing sub-groups of drivers. Transportation Research Part F. 2014;26: 82-91. Available from: doi:10.1016/j.trf.2014.06.008 